\title{
Students' Expectation and Mathematics Teachers Exhibition of Effective Instruction and Desirable Classroom Assessment Behaviour in Liberian Secondary Schools
}

\author{
Younn J., Nenty, H. J., \& Hinneh, J. T.
}

\begin{abstract}
Failure by teachers to meet students' expectations on desirable classroom instruction and assessment constitutes an assessment related problem in mathematics learning. The purpose of this study was to examine the relationship between students' expectation and mathematics teachers' exhibition of desirable classroom assessment behaviour. The study adopted a quantitative research approach and used the inferential survey design, which ensured close monitoring and supervision of both data collection and analysis and made interpretation easy. Using cluster sampling and systematic sampling techniques, the sample of $88712^{\text {th }}$ grade students was selected from the target population of all secondary school students in Liberia enrolled during the time of the study. A Survey questionnaire was used in this study and data was analyzed using paired sample ttest at the significance level, .05. The study found significant difference between students' expectation and teacher exhibition of quality questioning, feedback, wait time, fairness of classroom assessment and motivation through classroom assessment. The study also revealed significant difference between students' expectation and teacher exhibition of content knowledge, variety instruction, clarity of presentation, and class engagement. Based on the findings, it was concluded that mathematics teachers engage students' in classroom discourse and align classroom assessment with agreed instructional objectives so as to bridge the gap between students' expectation and mathematics teachers exhibitionof desirable classroom instruction and assessment behaviour. The implications and recommendations are discussed.
\end{abstract}

Key terms: student's expectation, desirable classroom assessment behaviour, effective instruction.

\section{Introduction}

Classroom assessment is regarded as an essential component of the teaching and learning processes in schools (Goodrum, Hackling, \&Rennie, 2001 cited in Gao, 2012). It is a powerful tool available to teachers in determining the effectiveness of teaching and the progress of students in mathematics learning (Watering, Gijbels, Dochy, \&Rijt, 2008). Assessment is a means of enhancing learning through improving the process of learning, emboldening the love to learn and of documenting achievement as a product of the learning process. However, students come to mathematics classroom with certain expectations regarding how they will be assessed and how often. Teachers are expected to meet these expectations just the same way a patient expects the physician to diagnose their situation and provide solution therewith. Failure by teachers to meet students' expectations on classroom assessment constitutes an assessment related problem in mathematics learning.

Liberia has a $6-3-3$ system of education (MOE, 2014). The elementary school level requires six years, the junior high school level takes three years, and the senior high level goes for three academic years. Mathematics is taken by every student in Liberia who enrolls at any of these levels of education in the country. The place of mathematics in the educational system in Liberia cannot be overemphasized. Mathematics is applicable in all works of life: education, accounting, agriculture, health sciences, social sciences, engineering, physical sciences, and so forth. Furthermore, Mathematics plays a major role in certificating a candidate graduating from secondary school. A candidate who has a deficiency in mathematics in the examinations administered by the West African Examinations Council (WAEC) is never awarded WAEC certificate unless he/she clears such deficiency; even if he/she passes all other subjects in the examinations (WAEC, 2011).

Given the significance of mathematics, it is taken as a compulsory subject in Liberian schools. As a result students attending secondary schools are compelled to do mathematics simply because it is a required subject. Anecdotal comments from students showed that they were good at mathematics in the primary school and that they had initially planned to pursue further study in mathematics related subjects. However, students hope to pursue mathematic related areas is being short circuited due to the manner mathematics has been taught and assessedin schools. Teachersoften delay to return students' mathematics assignment and quiz papers on time, but even if they got their work back teachers do not review the questions for the students to identify their weaknesses. Another thing is that mathematics teachers expect instant answers to questions they post to the class, which do not provide wait time to enable students to adequately attempt the questions. According to Ottevanger, van den Akker, and de Feiter (2007, p. 19) asserted that classroom assessment behavior of many teachers tends to thwart standard of education set by a country The argument raise here is that classroom 
assessment should serve as meaningful sources of information for teachers and students; in the absence of an appropriate classroom assessment behavior it becomes difficult if not impossible for mathematics teachers to meet students' expectationsand exhibit desirable classroom assessment behaviour.

\section{Theoretical Foundation}

This study was based on a strong theoretical foundation as espoused by Creemers and Kyriakides (2006 \&2011). They developed the Dynamic model, which is empirically grounded and has been subjected to testing and verification. It is multilevel and predicated on the assumption that the relation of some instructional factors is curvilinear with achievement. Moreover, this model is characterized by 21 teaching practices, which are grouped under eight headings - orientation, structuring, questioning, teaching modelling, application, the classroom as learning environment, management of time, and assessment (Coe, Aloisi, Higgins, \& Major, 2014). According to the dynamic model, orientation is meant to provide objectives for specific

task in a lesson, structuring seeks to draw attention to main ideas and establish transitions between lesson parts, questioning involves posing variety of questions type and allow students time to respond and handling student response, teaching modelling require encouraging students in problem solving strategies. Furthermore, application demands the use of seatwork or small group task in the classroom, the classroom as learning environment requires establishing on-task behaviour through the teacher - student and student- student interactions, management of time demands maximizing students' engagement, and assessment require teacher to adopt and use appropriate techniques to collect information on student learning. Hence, this model was adapted to measure classroom level effectiveness of mathematics teachers in terms of exhibition of effective instruction and desirable classroom assessment behaviour.

\section{Statement of the Problem}

Failure by teachers to meet students' expectations on classroom assessment constitutes an assessment related problem in mathematics learning as most secondary school students continue to perform poorly in mathematics. The problem is most teachers in Liberia are yet to utilize the strength of classroom assessment in boosting teaching effectiveness and enhancing learners' performance as the result they tend to shrink the level of the students' achievement rather than helping to extend the horizon of their mathematics knowledge, problem-solving skills, and application. This has raised concern from various stakeholders and public fear that the country might lose significant number of human potentials especially in mathematics related field if the situation is not swiftly tackled and remedied. It might stray potential senior secondary school students who crave to pursue studies in mathematics related fieldto make a detour for other disciplines. Hence, this study was initiated based on the fact that there is lack of information about mathematics teacher classroom assessment behavior and how it influences students' performance in mathematics.

\section{Purpose of the Study}

The study attempted to examine the relationship between students' expectation and mathematics teachers' exhibition of desirable classroom assessment behaviour.

\section{Research Hypotheses}

Two hypotheses were tested at the significance level of .05 as follows:

$\mathrm{H}_{1}$ : There is a significant difference between students' expectation and mathematics teachers' exhibition of desirable classroom assessment behaviour in Liberian senior high school.

$\mathrm{H}_{2}$ : There is a significant difference between students' expectation and mathematics teachers' exhibition of effective instruction in Liberian senior high school.

\section{Literature Review}

The quality a teacher possesses does not make him or her to display effective teaching in the classroom, but the extent to which their qualities meet students' expectation as well of national standard (Strong, Gargani, \&Hacifazlioglu(2011). Hence, effective mathematics teaching requires teacher understanding what students know, what students need to learn and then engaging students to learn well (Stronge, 2007).Coe,Aloisi, Higgins, and Major (2014) revealed six common features that describe effective instruction: content knowledge - teacher knowledge of the subject they teach, quality of instruction - teacher ability to engage in effective

questioning and give adequate time for students to practice, teaching climate - teacher quality of building a good teaching and learning relationship with students, classroom management - teacher efficient use of lesson time, manage resources, and students behaviors, teacher beliefs - reasons teacher adopt certain practices and purposes in the classroom, and professional behavior - teacher ability to be a life-long learner. These studies have found evidence that the quality of 
teacher teaching effectiveness have impact on student outcomes. But Westwood, 2004) demonstrated that effective teaching foremost requires clarity in presentations and explanations.Good and Brophy, 2003 also confirmed that these teaching effectiveness features are exhibited by teachers regardless of the school subjects they are teaching. Assessment is an important part of effective teaching which is expected to align with instructional objectives. According to Gao (2012), classroom assessment should support the learning of mathematics and provide useful information to both teachers and students. With this link, it is expected teacher classroom assessment behaviour should meet students expectation, thus improving achievement in mathematics.

\section{Methodology}

The study was underpinned by the positivist paradigm and adopted a quantitative research approach, as a belief system which dominated most of research (Johnson, 2014). This study used the inferential survey design, which enhanced the generalizability of the findings to the population from the sample was drawn(Chilisa\&Preece, 2005). This design also ensured close monitoring and supervision of both data collection and analysis and made interpretation more easy. The target population included all secondary school students in Liberia enrolled during the time of the study. In this study, cluster sampling and systematic sampling techniques were used to select schools and participants. These techniques made it possible to obtain a representative number of schools and participants from the mass of schools in the different regions. The sample of the study was 887 12th grade students enrolled for academic year 2013-2014.

Given the dynamic model, Creemers and Kyriakides (2011) developeda set of instruments measuring teacher effectiveness, which consisted of two low-inference classroom observation instruments, a high inference observational instrument and a student questionnaire, and a teacher questionnaire for measuring school factors. However, in this study a survey questionnaire was used to measure these practices from the students' perspective. The survey questionnairemade it possible to collect data from a wide range of students in a short time.

In regards to research ethics, research permit was obtained from the Ministry of Education republic of Liberia. Participants signed a consent form as a way of ensuring their willingness to participate in the study. The data was analyzed using paired sample t-test at the significance level, .05 as it reduces chances of making type I error (Kerlinger\& Lee, 2000).

$\mathrm{Ho}_{1}$

\section{Results}

There is no significant difference between students' expectation and mathematics teachers' exhibition of desirable classroom assessment behaviour in Liberian senior high school.

A paired-samples t-test was performed to compare students' expectation of mathematics teachers' classroom assessment behaviour and teachers' exhibition of desirable classroom assessment behaviour. There was a significant difference in the scores for the level to which students' prefer quality questioning $(\mathrm{M}=12.7$, $\mathrm{SD}=1.67)$ and the extent teachers' exhibit quality questioning $(\mathrm{M}=6.41, \mathrm{SD}=2.05)$; like quality feedback $((\mathrm{M}$ $=14.11, \mathrm{SD}=1.06)$ and teachers exhibit quality feedback $(\mathrm{M}=4.5, \mathrm{SD}=1.71)$, and preference of teacher's wait time $(\mathrm{M}=18.46, \mathrm{SD}=1.49)$ and teacher's exhibit of wait time $(\mathrm{M}=8.42, \mathrm{SD}=1.22), \mathrm{t}(886)=64.099, \mathrm{p}<$ $.001, \mathrm{t}(886)=126.018, \mathrm{p}<.001$, and $\mathrm{t}(886)=102.006, \mathrm{p}<.001$ respectively. There was also significant difference between students preference of fairness in assessment $(\mathrm{M}=9.28, \mathrm{SD}=1.22)$ and teacher's display of fairness in assessment $(\mathrm{M}=5.43, \mathrm{SD}=1.38)$; and students preference of motivation through classroom assessment $(\mathrm{M}=9.00, \mathrm{SD}=1.25)$ and extent to which teacher motivate students through classroom assessment $(\mathrm{M}=4.66, \mathrm{SD}=1.45), \mathrm{t}(886)=65.005, \mathrm{p}<.001$ and $\mathrm{t}(886)=66.137, \mathrm{p}<.001$ respectively (See Table 1$)$. These results suggest that students' preference of mathematics teachers' classroom assessment behaviour is different from the extent to which teachers' exhibit classroom assessment behaviour. In other words, the results mean that the higher students' prefer teacher classroom assessment behavior the lesser teachers tend to exhibit these behaviors.

Table 1: Paired Sample t-Test of students' expectation of mathematics teachers' classroom assessment behaviour and teachers' exhibition of desirable classroom assessment behaviour $(\mathrm{df}=886)$

\begin{tabular}{|c|c|c|c|c|c|c|c|c|}
\hline Pair & Variable & $\mathrm{X}$ & SD & $\mathrm{r}$ & Mean Diff & Std. Error Diff & $\mathrm{t}$ & Sig. (2-tailed) \\
\hline \multirow[t]{2}{*}{1} & $\begin{array}{l}\text { Level to which students prefer } \\
\text { quality questions }\end{array}$ & 12.7 & 1.67 & -.23 & \multirow[t]{2}{*}{6.2886} & \multirow[t]{2}{*}{.09811} & \multirow[t]{2}{*}{64.09} & \multirow[t]{2}{*}{$.000^{*}$} \\
\hline & $\begin{array}{l}\text { Extent to which teachers provide } \\
\text { quality questions }\end{array}$ & 6.41 & 2.05 & & & & & \\
\hline \multirow[t]{2}{*}{2} & $\begin{array}{l}\text { Level to which students like } \\
\text { quality feedback }\end{array}$ & 14.1 & 1.06 & -.31 & \multirow[t]{2}{*}{9.6054} & \multirow[t]{2}{*}{.076220} & \multirow[t]{2}{*}{126.02} & \multirow[t]{2}{*}{$.000 *$} \\
\hline & $\begin{array}{l}\text { Extent teachers give quality } \\
\text { feedback }\end{array}$ & 4.50 & 1.71 & & & & & \\
\hline 3 & Students preference of teachers' & 18.5 & 1.49 & -.25 & 10.044 & & 102.01 & $.000 *$ \\
\hline
\end{tabular}


Students' Expectation and Mathematics Teachers Exhibition of Effective Instruction and Desirable...

\begin{tabular}{|c|c|c|c|c|c|c|c|c|}
\hline & wait time duration & & & & & \multirow[t]{2}{*}{.09846} & & \\
\hline & $\begin{array}{l}\begin{array}{l}\text { Extent of teachers' wait time } \\
\text { duration }\end{array} \\
\end{array}$ & 8.42 & 2.18 & & & & & \\
\hline \multirow[t]{2}{*}{4} & $\begin{array}{l}\text { Students preference of teachers } \\
\text { fairness in assessment }\end{array}$ & 9.28 & 1.22 & .08 & \multirow[t]{2}{*}{3.85118} & \multirow[t]{2}{*}{.05924} & \multirow[t]{2}{*}{65.005} & \multirow[t]{2}{*}{$.000^{*}$} \\
\hline & $\begin{array}{l}\text { Level to which teachers are fair in } \\
\text { classroom assessment }\end{array}$ & 5.43 & 1.38 & & & & & \\
\hline \multirow[t]{2}{*}{5} & 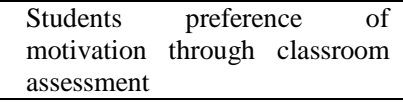 & 9.00 & 1.25 & -.04 & \multirow[t]{2}{*}{4.34386} & \multirow[t]{2}{*}{06568.} & \multirow[t]{2}{*}{66.137} & \multirow[t]{2}{*}{$.000^{*}$} \\
\hline & $\begin{array}{l}\text { Extent teachers motivate students } \\
\text { through classroom assessment }\end{array}$ & 4.66 & 1.45 & & & & & \\
\hline
\end{tabular}

Note: * significant at .05 at 2-tailed

$\mathrm{Ho}_{2}$ :

There is no significant difference between students' expectation and mathematics teachers' exhibition of effective instruction in Liberian senior high school.

A paired-samples t-test was conducted to compare students' expectation of mathematics teachers' effective instruction and teachers' exhibition of effective instruction. There was a significant difference in the scores for students preference of teacher content knowledge $(M=18.87, S D=1.54)$ and teachers' exhibition of content knowledge $(M=13.78, S D=2.57)$ andstudents' preference of variety instruction $(M=14.25, S D=$ $1.32)$ and teachers exhibitionof variety instruction $(M=6.80, S D=1.64), t(886)=55.218, p<.001$ and $t(886)=$ $94.479, p<.001$ respectively.

The results also showed significant difference between students preference of clarity of presentation $(M$ $=13.91, S D=1.29)$ and teacher's display of exhibition of clarity of presentation $(M=9.80, S D=2.09)$ and students preference of classroom engagement $(M=18.72, S D=1.46)$ and extent to which teacher engage students in the classroom $(M=8.43, S D=2.36), t(886)=50.96, p<.001$ and $t(886)=108.262, p<.001$ respectively (See Table 2).

These significant results suggest that students' preference of effective instruction is different from the way teachers' exhibit effective instruction in mathematics classroom. The results signify that the more students prefer effective instruction the lesser teachers tend to exhibit effective instruction in mathematics classroom.

Table 2: Paired Sample t-Test of students' expectation of mathematics teachers' effective instruction and teachers' exhibition of effective instruction $(\mathrm{df}=886)$

\begin{tabular}{|c|c|c|c|c|c|c|c|c|}
\hline Pair & Variable & $X$ & SD & $\mathrm{r}$ & Mean Diff & Std. Error Diff & $\mathrm{t}$ & $\begin{array}{l}\text { Sig. (2- } \\
\text { tailed) }\end{array}$ \\
\hline \multirow[t]{2}{*}{1} & $\begin{array}{l}\text { Students preference of teachers } \\
\text { content knowledge }\end{array}$ & 18.8726 & 1.54343 & .180 & \multirow[t]{2}{*}{5.09470} & \multirow[t]{2}{*}{09226} & \multirow[t]{2}{*}{55.218} & \multirow[t]{2}{*}{$.000^{*}$} \\
\hline & $\begin{array}{l}\text { Level to which teachers exhibit } \\
\text { content knowledge }\end{array}$ & 13.7779 & 2.56897 & & & & & \\
\hline \multirow[t]{2}{*}{2} & $\begin{array}{l}\text { Students preference of variety } \\
\text { of teachers' instruction }\end{array}$ & 14.2503 & 1.31601 & -.250 & \multirow[t]{2}{*}{7.44758} & \multirow[t]{2}{*}{.07883} & \multirow[t]{2}{*}{94.479} & \multirow[t]{2}{*}{$.000^{*}$} \\
\hline & $\begin{array}{l}\text { Level to which teachers use } \\
\text { variety of instruction }\end{array}$ & 6.8027 & 1.64257 & & & & & \\
\hline \multirow[t]{2}{*}{3} & $\begin{array}{l}\text { Students preference of teachers } \\
\text { clarity of presentation }\end{array}$ & 13.9121 & 1.29818 & .054 & 4.10936 & .08064 & 50.960 & $.000 *$ \\
\hline & $\begin{array}{l}\text { Level to which teachers make } \\
\text { clear presentation }\end{array}$ & 9.8027 & 2.09225 & & & & & \\
\hline \multirow[t]{2}{*}{4} & $\begin{array}{l}\text { Students preference of } \\
\text { classroom engagement }\end{array}$ & 18.7159 & 1.45838 & -.040 & 10.28298 & .09498 & 108.262 & $.000 *$ \\
\hline & $\begin{array}{l}\text { Teachers level of classroom } \\
\text { engagement of students }\end{array}$ & 8.4329 & 2.36599 & & & & & \\
\hline
\end{tabular}

Note: * significant at .05 at 2-tailed

\section{Discussions and Implication}

This study was initiated to addresses the research gap resulting from the lack of empirical research on the relationship between student expectations and mathematics teachers' exhibition of desirable classroom assessment behaviour and effective instruction withinthe context of Liberian secondary education. Thestudy found significant difference between students' expectation and teacher exhibition of quality questioning, feedback, wait time, fairness of classroom assessment and motivation through classroom assessment. This result can possibly be attributed to the fact that mathematics teachers in Liberian secondary school usually do not discuss learning objectives with students and so students find themselves in a vacuum not knowing what to expect from their teachers in terms of classroom assessment. In other words, this finding possibly resulted in terms of the gap between the classroom assessment behaviour that mathematics teachers exhibit and students' ignorance of the classroom assessment behaviour they prefer.Generally, Liberian teachers tend to consider 
paper-and-pencil tests or examinations as the only or best classroom assessment tools to measure their students' performance. Teachers classroom assessment behavior is not cognitively productive and tends to relegate learning to acquiring recall skills and cramming taught materials for a single examination. Even though mathematics teachers' classroom assessment behaviour is contrary to what students' expect in the classroom, the finding suggest that mathematics teachers should strive hard to align their classroom assessment with instructional objectives as well as discuss same with students so as to meet students' expectation.

Secondly, the study revealed significant difference between students' expectation and teacher exhibition of content knowledge, variety instruction, clarity of presentation, and class engagement. The finding diverge from Westwood (2004) who assert that effective teaching foremost requires clarity in presentationsand explanations as well as Good and Brophy (2003)who demonstrated that teachers exhibit effective teachingregardless of the subjects they are teaching. This implies that the quality a mathematics teacher possesses does not make him or her to display effective teaching in the classroom (Stronge, 2007). To exhibit effective instruction, mathematics teachers need to understand what students know, what students need to learn,and engage students to learn well by making sure that students understand instructional objectives and establish their expectation of their teacher instruction. These findings confirmed the dynamic model of educational effectiveness at the classroom level as espoused by Creemers and Kyriakides (2006) in that the study reveal similar practices of mathematics teachers at the classroom level. Additionally, the study was able to model the link between students' expectation and mathematics teachers exhibition of effective instruction and desirable classroom assessment behaviour.

\section{Conclusion}

This study sought to examine the relationship between students' expectation and mathematics teachers' exhibition of effective instruction and desirable classroom assessment behaviour.Given the results of the study, it can be concluded that students' expectation of desirable effective instruction and classroom assessment behaviour is different from how their teachers exhibit desirable effective instruction and classroom assessment behaviour. Specifically, the way students expect mathematics teachers to display content knowledge, variety instruction, clarity of presentation, and class engagement is different from how their teachers exhibit these qualities. Similarly, the manner in which mathematic teachers' exhibit quality questioning, feedback, wait time, fairness of classroom assessment and motivation through classroom assessment diverges from their students' expectations. Therefore, it can be that mathematics teachers should engage students' in classroom discourse and align classroom assessment with agreed instructional objectives so as to bridge the gap between students' expectation and mathematics teachers display of desirable classroom instruction and assessment behaviour in Liberian secondary school. However, the findings of this study may be limited and so the results should be interpreted with caution.

\section{Recommendations}

Based on the findings, the following recommendations are suggested:

1. Mathematics teachers should engage students in classroom assessment. This can be achieved by discussion classroom assessment with students and aligning classroom assessment to the agreed instructional objectives. As a result, there will be an association between the classroom assessment behaviour teachers' exhibit and the classroom assessment behaviour students expect in their mathematics classroom.

2. Mathematics teachers should engage students in instructional discourse. This can be done by making discourse will help close the gap between what students expect and what teacher exhibit in terms of effective instruction in the classroom.

3. Further learning objectives clear to students and encouraging students to set expectations for lessons. This kind of instructional study is needed to establish how teacher exhibition of effective instruction and desirable classroom assessment behaviour affect students' achievement in mathematics.

\section{Reference}

[1] Chilisa, B., \&Preece, J. (2005). Research methods for adults in Africa: African perspectives on adult learning. Gaborone: Pearson.

[2] Coe, R., Aloisi, C., Higgins, S., \& Major, L. E. (2014). What makes great teaching?Review of the underpinning research. Retrieved from http://www.suttontrust.com/wp-content/uploads/

[3] Creemers, B. P. M., \&Kyriakides, L. (2006). Critical analysis of the current approaches to modelling educational effectiveness: The importance of establishing a dynamic model. School Effectiveness and School Improvement , 17, 347- 366. Retrieved from http://www.rug.nl/staff/b.p.m

[4] Creemers, B. P., \&Kyriakides, L. (2011). Improving quality in education: dynamic approaches to school improvement . Routledge, Taylor \& Francis Group.

[5] Gao, M. (2012). Classroom assessment in mathematics: High school students' perceptions. International Journal of Business and Social Sciences, 3 (2).

[6] Good, T. L., \& Brophy, J. E. (2003). Looking in the classroom (9 $9_{\mathrm{th}}$ ed.). Boston: Allyn \& Bacon.

[7] Johnson, S. (2014). Advantages and disadvantages of positivism. Retrieved from http//:www.ehow.com/info_12088541_advantages-disadvantages-positivism.html 
[8] Kerlinger, F. N., Lee, H. B. (2000). Foundations of behavioral research (4th ed.). New York: Cengage.

[9] Ministry of Education. (2014). Ministry of education annual report 2014. Government print, Republic of Liberia.

[10] Ottevanger, W., van den Akker, J., \& de Feiter, L. (2007). Developing science, mathematics, and ICT education in sub-Saharan Africa: Pattern and promising practices. Washing, D. C.: The World Bank.

[11] Stronge, J. H. (2007). Qualities of Effective Teachers (2nd ed.). ISBN-13: 978-1-4166-0461-7

[12] Retrieved from rethttp://www.ascd.org/publications/books/105156/

[13] Strong, M., Gargani, J., \&Hacifazlioglu, O. (2011). Do we know a successful teacher when we see one? Experiments in the identification of effective teachers. Journal of Teacher Education, 62(4), 367-382. Retrieved from http://jte.sagepub.com/content/62/4/367

[14] Watering, G., Gijbels, D., Dochy, F., \&Rijt, J. (2008). Studentsassessment preferences, perceptions of assessment andtheir relationships to study results.Higher Education, 56, 645-658.

[15] West African Examinations Council. ([WAEC], 2011). Liberia: Over 12,000 pass WAEC-as Firestone student hits Div. 1. Monrovia: WAEC (Author).

[16] Westwood, P. (2004). Effective teaching to reduce educational failure. Journal of Learning Disabilities, 3 (3), 4-12. Retrieved from http://www.thrass.com.au/wp-content/uploads/ 